\title{
Enhancement of the Transfection Efficiency of Poly(ethylenimine) by Guanidylation
}

\author{
Yan Lee, ${ }^{\dagger}$ Min Yi Cho, Hecjung Mo, Kihoon Nam, Hecbeom Koo, Geun-woo Jin, and Jong Sang Park ${ }^{*}$
}

\author{
School of Chemisty and Molectlar Engineering, Seowl National University. Seotd 151-742, Korea \\ E-mail: pjsparkiaplaza.smu.ac,kr \\ "Division of Clinical Biotechnology, Center for Disease Biologn and Integraite Medicine, Gradtate School of Medicine, \\ The Liniversity of Tokyo, Tokvo 113-8656. Japan \\ Received November 19, 2007
}

Key Words : Gene delivery, Guanidine, Polymer, Transfection

Chemists have not only developed new drugs but also some novel inethodology for drug or gene delivery. Both the synthesis of new delivery carrier and the development of new formulation of existing materials could be a good target of chemists in these fields. Previously, gene delivery had also belonged to only biological field owing to the viral vector.' but it entered into the area of chemistry after the development of synthetic non-viral vectors. ${ }^{2}$

Several non-viral vectors composed of polymers. ${ }^{3}$ lipids, ${ }^{+}$ metals, ${ }^{5}$ etc. have various inerits over viral vectors including low toxicity, mass production, and the capacity for the gene even though they had relatively lower transfection efficiency than the viral vectors. Some polymeric vectors, such as poly(ethylenimine) ( $\left.\mathrm{I}^{\mathrm{E} E} \mathrm{l}\right)^{6}$ and poly(amidoamine) (PAMAM) ${ }^{7}$ showed the highest transfection efficiencies among non-viral gene delivery vectors, which were comparable to those of the viral vectors. It was suggested that the high transfection efficiency of PEI or PAMAM could be explained by the endosome buffering effect originated from its high charge density or membrane disruption."

The transfection efficiency of these polymers is highly dependent upon their molecular weights. For example, whereas l'El with the molecular weight over $25 \mathrm{kDa}$ showed the highest transfection efficiency among all non-viral gene delivery vectors, ['El with low molecular weight showed much less transfection efficiency."

However, toxicity, which is another important factor for the in vivo gene delivery, increases sharply as the molecular weight increases. The P'El $2 \mathrm{kD}$ a shows almost no toxicity, but PE] $25 \mathrm{kDa}$ showed very high toxicity both in vitro and in vivo applications. Therefore, there have been many efforts to combine the merits of these two types of PEl-high transfection efficiency of high-molecular-weight l'El and low toxicity of low-molecular-weight PEI- for an ideal gene delivery vector. For example, several derivatives of lowmolecular-weight PE] were linked with biodegradable bonds for enhancing transfection efficiency, with limiting success. ${ }^{10}$

Meanwhile, it has been reported that arginine residues in the IAT viral protein sequence could improve the delivery efficiency into the cell nucleus. " Other polymers conjugated with IAI sequence or arginine-rich sequence also showed high transfection efficiency. In our previous report, the PAMAM dendrimer showed significantly improved transfection efficiency after the modification of the surface with arginine. $^{12}$

Because there is a specific guanidine residue other than primary amine in arginine, it is supposed that we can improve the transfection efficiency of PEI by the modification of its primary amine into guanidine. In this paper, we will report how to improve the transfection efficiency of low-molecular weight PEI as well as to maintain its low toxicity.

The modification of primary amines in PEl $2 \mathrm{kDa}$ into guanidines is performed using pyrazole-1-carboxamidine (Figure 1). As a control, the amines in high-Inolecularweight PE] $25 \mathrm{kDa}$ was also converted to guanidines. PEl in $0.01 \mathrm{M}$ potassium carbonate aqueous solution was added with 5 equivalents of pyrazole-l-carboxamidine per each primary amine residue. The reaction mixture was stirred at r.t. for $20 \mathrm{hr}$, dialyzed against distilled water, and lyophilized to get the final product, poly(ethylenimine guanidine) (lPEGu).

${ }^{1} \mathrm{H}-\mathrm{NMR}$ and elemental analysis were used for the measurement of amine-guanidine conversion ratios. 12\% (25 kDa) and 19\% (2 kDa) of total amine residues in PEl

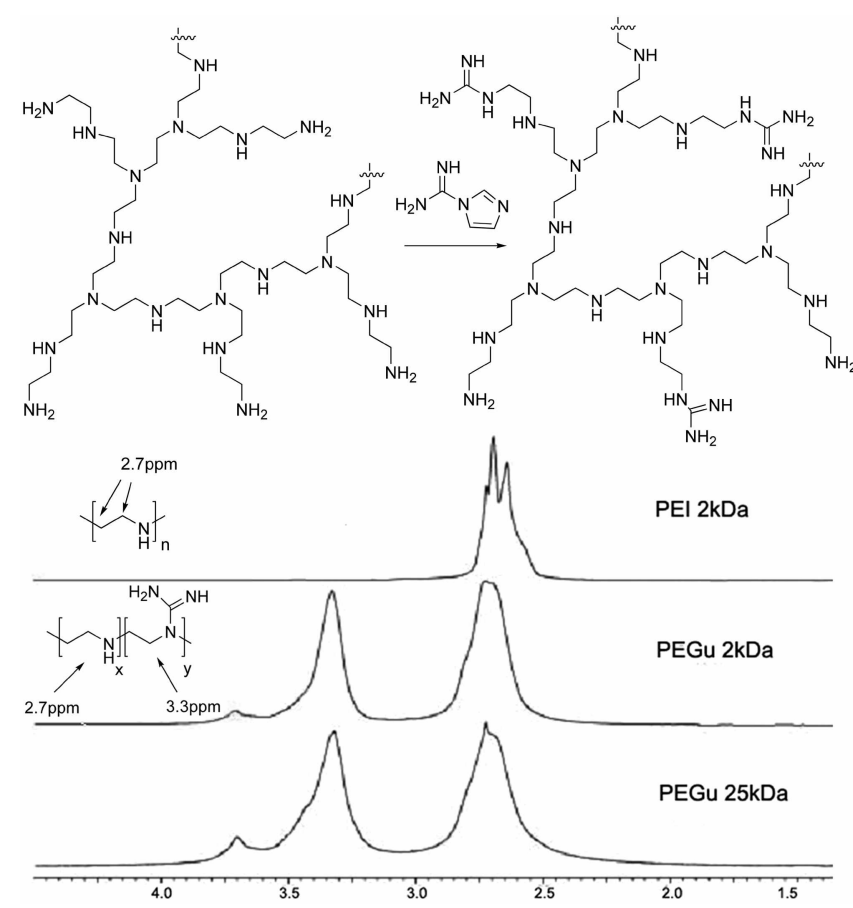

Figure 1. Synthetic scheme of PLCiu synthesis and "II-NMR spcctrums of PEl and PEGu. 


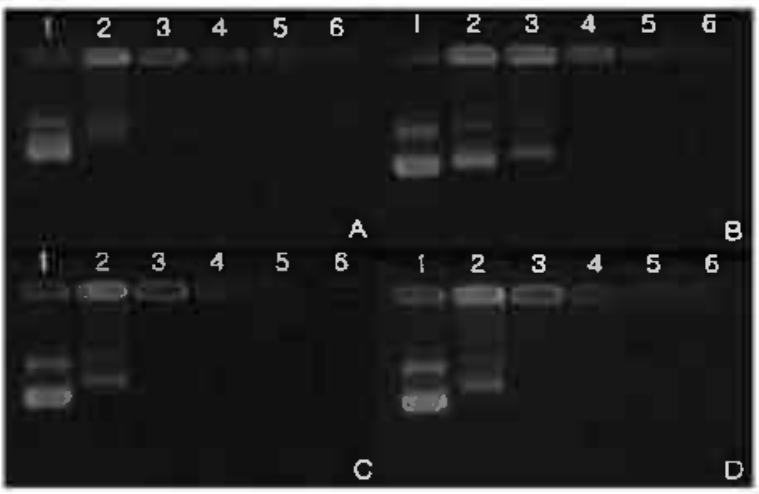

Figure 2. Agarose gel retardation assay of plasmid D $\vee A$ and PEI $25 \mathrm{kDa}(\mathrm{A})$. PFGu $25 \mathrm{k}$ Da (B). PEI $2 \mathrm{kDa}$ (C). PEGu $2 \mathrm{kJa}$ (D). Plasmid IJNA $(1, a \mathrm{~g})$ only (lane 1$)$. N/P ratio of polymerioNA I, 2. 4,8 and 11 (lanes $2,3,4,5$, and 6 respectively).

were converted into guanidine. Considering that the primary amine groups are $25 \%$ of total amine groups in PEI, the primary amine-guanidine conversion yields are $48 \%(25$ $\mathrm{kDa}$ ) and $76 \%$ (2 kDa). These conversion yields by pyrazole-l-carboxamidine are similar to that in the previous report. ${ }^{13}$ The reason of the lower conversion yield of PEI 25 kDa was probably because the portion of the exposed primary amines in PE'] $25 \mathrm{kDa}$, which could react with pyrazole-1-carboxamidine easily, was lower than that in PEI $2 \mathrm{kDa}$.

Because the electrostatic complex formation between cationic polymers and anionic DNA is very important for transfection. the complex formation ability of initial PEI and PEGu were compared each other using well-known agarose gel electrophoresis method (Figure 2). The numbers in the figure represent the ratios between moles of (amine $(N)+$ guanidine $(G)$ ) residues in polymers and moles of phosphate (P) residues in DNA. As shown in the figure, the mobility of DNA with l'EGu was retarded at $(\mathrm{N}+\mathrm{G}) / \mathrm{P}$ ratio around 3 in both molecular weights. Although the complex formation abilities of l'EGus are slightly weaker than those of initial PEls, the differences are not so significant. The polymerDNA complex can be formed easily after the conversion from P'E] to l'EGu.

The transfection on the mouse myoblast $\mathrm{C} 2 \mathrm{C} 12$ cell line was performed with the polymer-DNA complex (Figure 3). PEGu $25 \mathrm{kDa}$ showed $30 \%$ higher transfection efficiency than unmodified P'El $25 \mathrm{kDa}$. The transfection increase by guanidylation is more remarkable in the transfection by lowmolecular weight polymers. As mentioned above, the transfection efficiency of the unmodified PEl $2 \mathrm{kDa}$ is only one tenth of that of PEI $25 \mathrm{kDa}$ at their optimal conditions. However, after the guanidylation, PEGu $2 \mathrm{kDa}$ showed 20 times higher efficiency than l'El $2 \mathrm{kDa}$ and two times higher than PEI $25 \mathrm{kDa}$. Moreover, the transfection efficiency of PEGu $2 \mathrm{kD}$ a was eight times higher than that of PE] $25 \mathrm{kDa}$ in presence of $10 \%$ fetal bovine serum condition, which was more similar to the in vivo environment.

As mentioned above, the transfection efficiency of highmolecular-weight $\mathrm{P}$ 'EI is largely dependent upon the endo-

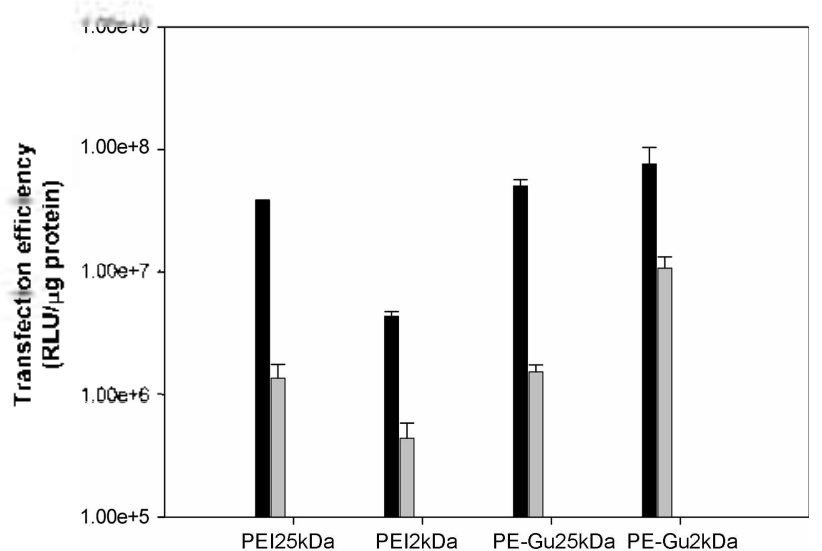

Figure 3. Transfection efficiency on C2C12 cell lines. Black hars represent FBS-free condition. and gray bars represent FBS condition. The numbers represent weight ratios between IDSA and polymers. The enror bars mean standard deviation of three experiments.

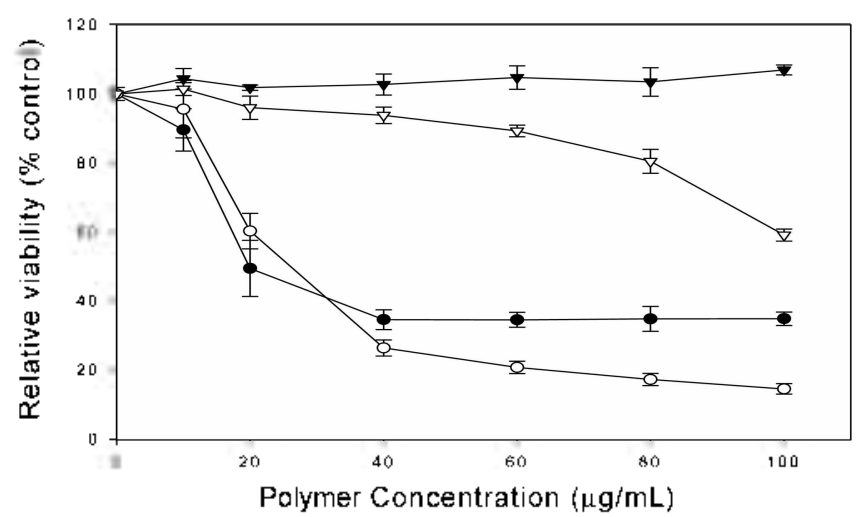

Figure 4. Cytotoxicity assay on $\mathrm{C} 2 \mathrm{C} 12$ cells of PEl $25 \mathrm{kDa}(\bullet)$ PFGu $25 \mathrm{k}$ ba (O). PE.I $2 \mathrm{kDa}(\mathbf{v})$. and PECiu $2 \mathrm{kDa}(\because)$. The ejror bats mean standard deviation of six experiments.

some buffering effect of its unprotonated amines. Whereas the guanidylation could facilitate the nucleus localization of the gene, the resulting decrease of unprotonated amine density could inhibit the endosome buffering effect somewhat. Therefore, the final transfection efficiency of the PEGu 25 $\mathrm{kDa}$ was not increased so much. Meanwhile, it is supposed that the transfection of low-molecular-weight PEl could not proceed by the endosome buffering effectively, so that the guanidylation could increase the transfection efficiency over 20 times.

Because our main objective was the development of the gene delivery carrier with low toxicity as well as high transfection efficiency, the cytotoxicity of $\mathrm{P} E \mathrm{E}$ (u was also analyzed in the $\mathrm{C} 2 \mathrm{C} 12$ cell line (Figure 4 ). The cytotoxicities of the PEGus increased slightly comparing to those of their corresponding PEIs. However, $\mathrm{IC}_{50}$ value of PEGu $2 \mathrm{kDa}$ is more than five times of that of P'El $25 \mathrm{kDa}$. Considering that the transfection efficiency of the l'EGu $2 \mathrm{kDa}$ was two times higher than PEI $25 \mathrm{kD}$ a, the guanidylation of low-molecularweight l'El could be a good way to obtain an efficient and safe gene delivery carrier. The concentration of the gene delivery carrier for the transfection is generally below 20 
$\mathrm{mg} / \mathrm{mL}$, so that the toxicity of PEGu $2 \mathrm{kDa}$ could be negligible

In sunmary. we could improve the trasufection efficiency of PEI $2 \mathrm{kDa} 20$ times by guanidylation as well as maintain its low cytotoxicity. The guanidylated polymer, PEGu, can be a potential gene delivery carrier, and the guanidy lation of primary amine groups can be applied to increase the transfection efficiency of other cationic polymers for gene delivery.

\section{Experimental Section}

The synthesis of PEGu. PEI $(0.010 \mathrm{~mol}$ anine residues/ L) was dissolved in potassium carbonate aqueous solution. The concentration of potassium carbonate is $0.050 \mathrm{~mol} / \mathrm{L}$. The solution was added with pyrazole-l-carboxamidine (5 eq. per amine residue). The reaction mixture was stirred for $20 \mathrm{~h}$ and purified by dialysis (M.W.C.O = 1,000 Da: Hankook Spectrum $\mathrm{Co}$.) against distilled water to obtain their corresponding PEGus. The ${ }^{1} \mathrm{H}-\mathrm{NMR}$ spectrums of PEI and PEGu were shown in Figure 1. The conversion yield could be calculated from the elemental analysis data. The conversion yield is $12 \%$ and $19 \%$ for PEI $25 \mathrm{kDa}$ and PEI $2 \mathrm{kDa}$. respectively.

Agarose gel electrophoresis. DNA-polymer complexes were formed at different charge ratios between the polymer and $\mathrm{pCN}$-Luciferase (pCN-Luci) plasmid by incubating in HEPES buffer ( $25 \mathrm{mM}$. PH 7.4, $\left.10 \mathrm{mM} \mathrm{MgCl}_{2}\right)$ at rt for 30 $\mathrm{min}$. Each sample was then analyzed by electrophoresis on a $0.7 \%$ agarose gel and stained by incubation for $1 \mathrm{~h}$ in buffer containing ethidium bromide $(0.5 \mu \mathrm{g} / \mathrm{mL})$ at $37^{\circ} \mathrm{C}$.

Transfection assay in the $\mathrm{C} 2 \mathrm{C} 12$ cell line. The $\mathrm{C} 2 \mathrm{Cl} 2$ cells were seeded at a density of $5 \times 10^{4}$ cells/well in 24-well plates in $600 \mu \mathrm{L}$ of media containing $10 \%$ Fatal Bovine Serum (FBS) and grown to $70-80 \%$ confluence. The cells were treated with polvplex solution containing $2 \mu \mathrm{g}$ of plasmid DNA at different $\mathrm{N} / \mathrm{P}$ ratios for $4 \mathrm{~h}$ at $37^{\circ} \mathrm{C}$. Following $+\mathrm{h}$ treatment of polyplexes, the medium was replaced by $600 \mu \mathrm{L}$ of fresh medium containing $10 \%$ FBS. Cells were incubated further for 2 day's before the luciferase assay. Then the growth medium was removed. and the cells were rinsed with phosphate buffered saline and ly'sed for 30 min at room temperature using $150 \mu \mathrm{L}$ of Reporter lysis buffer (Promega). Luciferase activity was measured using a LB 9507 luminometer (Berthold. Germany) and the protein content was measured by using a Micro BCA assay reagent kit (Pierce. Rockford. IL).

Cytotoxicity assay. For the cytotoxicity assay, the colorimetric MTT assay was perfonmed. Briefly, HepG2 cells were seeded at a density of $5 \times 10^{3}$ cells/well in a 96-ivell plate and ground in $90 \mu \mathrm{L}$ of media for 1 day prior to the incubation with polymers. After treating cells with PEI 2 $\mathrm{kDa}$. PEI $25 \mathrm{kDa}$. PEGu $2 \mathrm{kDa}$. and PEGu $25 \mathrm{kDa}$ for $\mathrm{I}$ day, $25 \mu \mathrm{L}$ of MTT stock solution $(5 \mathrm{mg} / \mathrm{mL})$ was added each well and incubate further $2 \mathrm{~h}$. Then $100 \mu \mathrm{L}$ extraction buffer $\left(20 \% \mathrm{w} / \mathrm{v}\right.$ of SDS is dissolved at $37^{\circ} \mathrm{C}$ in a solution of $50 \%$ of each DMF and water. using magnetic stirring: $\mathrm{pH}$ is adjusted to 4.7 by adding $2.5 \%$ of an $80 \%$ acetic acid and $2.5 \% \mathrm{I} \mathrm{N} \mathrm{HCl}$ ) was added, and incubate overnight at $37^{\circ} \mathrm{C}$ and the absorbance was measured at $570 \mathrm{~nm}$ using a microplate reader.

Acknowledgements. This work was supported by the Gene Therapy Project of the Ministry of Science and Technology (Ml053403004-05N3406-00410).

\section{References}

1. Verma. I. M.: Somia. N. Natwe 1997. 389. 239.

2. Pouton. C. W.: Seymour. L. W. Adv Drig. Del Rev 2001. 46. 187.

3. (a) Amiji. M. M. Pohmenic Gene Delineny: CRC Press: N. Y.. U.S.A. 2005. (b) Merdan. I.: Kopecek. J.: Kissel. I. Adh: Dumg. Delevery Rev 2002. 54. 715. (c) Kim. H. J:: Kwon. M. S.: Choi. J S.: Kim. B. H.; Yoon. J. K. Kim. K.: Park. J. S. B. Kor Chem Soc, $2007,28,63$.

4. (a) Templeton, N. S.: Lasic. D. D. 1 fol. Biotechol. 1999. 11,175 (b) Kinn. S. T.: Choi. J. S.: Chang. H. S.: Suhı. H.: Park. J. S. B. Kor. Chem. Soc. 2001. 22. 1069.

5. Choy. J.-H.: Kwak. S.-Y.: Teong. Y.-T.: Park. J-S. Angew: Chen. Int Ed. 2000, 39. 4041.

6. Godbey, W. T: Wu. K. K.: Mikos. A. G. I. Controlled Reteast? 1999. 60.149

7. Esfand. R: Tomalia. D. A. Drug Disconery Todav 2001. 6. 427.

8. Boussif. O.: Lezoulale'h. F.: Zanta. M. A.: Mergny: M. D.: Schermatl. D.: Demeneix. B.: Behr. J. P. Proc. Natl Acad Sci U.S.A. 1995, 92,7297 .

9. Gosselin, M. A.: Guo. W.; Lee, R. J. Bioconiugate Chem. 2001. 12. 989 .

10. Aht1. C.-H.: Chae. S. Y: Bae. Y. H.: Kim. S. W. J. ControlledRel. 2002. 80.273

11. Fuente. T. M.: Berry. C. C. Bioconingate Chent 2005. 16. 1176.

12. Choi. J. S.: Nam. K.; Park, J.y.: Kim. J.; Park, J. S. J. Comoolled Rel. 2004, 99, 445 .

13. Wender. P. A.: Rothbard, J. B: Jessop. T. C.: Kreider, E. L.: Wylie. B. L. J. An. Chem. Soc 2002. 124. 13382. 